\title{
North/South differentiation in the distribution of Cepaea nemoralis in Spain
}

L. I. Mazon,

A. Vicario, M. A. M. de Pancorbo,

A. I. Aguirre,

A. Estomba and

C. M. Lostao
Depto de Biologia Animal y Genetica, Facultad de Ciencias, Universidad del Pais Vasco, Apdo 644, 48080 Bilbao, Spain.

* Depto de Histologia y Biologia, Facultad de Medicina, Universidad del Pais Vasco, 48071 Bilbao, Spain.

Sixteen enzymatic loci of Cepaea nemoralis were studied in an area of $180 \mathrm{~km}$ long by $40 \mathrm{~km}$ wide in northern Spain. Two new polymorphic loci DIA and GLO, and two monomorphics, ARYL and $\beta-G A L$ are described.

The analysis of principal components groups the populations in two geographical areas, in the north and south of the sampling area. There is also an intermediate area between them. Heterozygosity in the northern area is significantly higher than in the southern one. Heterozygosity seems to diminish in unfavourable conditions (greater dryness or greater altitude), which is in accordance with the niche width variation hypothesis. There seems to exist an association between alleles of GLO and PGM and altitude.

The geographical areas created by the biochemical polymorphism coincide with those of the visible polymorphism, which in turn correspond to climatic zones. The northern area, according to visible and biochemical polymorphism is located in the so-called "Green Iberia", and the southern area in "Brown Iberia". The intermediate area corresponds to the area of climatic transition between them. These areas could correspond to "geographical races" of Cepaea nemoralis.

Climatic selection may be acting upon some loci such as PGM and GLO while in others random drift could be the cause of heterogeneity.

\section{INTRODUCTION}

Band pattern and colour polymorphism of the shell have been widely studied in the land snail Cepaea nemoralis, and much geographical variation revealed. In some areas, abrupt changes have been discovered in the frequency of morphs. These have been called "area effects" (Cain and Currey, 1963). These could correspond to parapatric or stasipatric speciation in the absence of geographical isolation (White, 1978). Biochemical polymorphism in Cepaea nemoralis is less studied (Manwell and Baker, 1968; Levan and Fredga, 1972; Oxford, 1973; Brussard and McCracken, 1974; Johnson, $1976,1979)$; it also shows wide geographical variation, as in the case of the Pyrenees (Jones et al., 1980; Cougant et al., 1982; Valdez-Forsans, 1983) and "molecular area effects" have even been detected (Ochman et al., 1983).

Large scale studies of visible (Jones et al., 1977) and biochemical (Ochman et al., 1987) polymorphism have demonstrated the existence of gradients in the frequencies. If the area effects were an early stage of speciation, a coincidence in variation could be expected between the loci of biochemical polymorphism and the morphological characters of the shells. In some places this association has been found, but not in others (Johnson, 1976; Jones et al., 1980).

In Cepaea nemoralis it has been postulated that climatic selection is acting upon visible polymorphism (see Jones et al., 1977). For biochemical polymorphisms, in other species, significant differences have been found in gene frequencies of different enzymatic loci between drier and warmer south-facing slopes and wetter and cooler north-facing slopes, e.g., Nevo et al. (1982). The different slope patterns appear to be adaptive, and are presumably maintained by microclimatic diversifying selection. On the other hand, Ochman et al. (1983) did not find differences between the north and south of the Pyrenees, but found three regions (East, Centre, West) which were relatively uniform, and would correspond to an allopatric differentiation model with subsequent secondary contacts. Selander and Kaufmann (1975) found 
that random drift was the cause of the differences between gene frequencies between populations of Helix aspersa.

For visible polymorphism, Mazon et al. (1987) found that the Cepaea nemoralis populations of northern Spain were grouped in two large geographical areas which coincide with the existence of two climatic zones: "Green Iberia" and "Brown Iberia". This suggested climatic selection as the cause of this division. The aim of this study is to learn whether the morphological differentiation of these two zones also manifests itself in biochemical polymorphism, and thus to be able to learn whether selection can act at a deeper level, such as the molecular level. If this is so, we have an apparent case of White's "geographical races" (White, 1978).

\section{MATERIALS AND METHODS}

Thirty-one populations were sampled along the $3^{\circ} \mathrm{W}$ meridian in an area $200 \mathrm{~km}$ long, and $40 \mathrm{~km}$ wide (Mazon et al., 1987), fig. 1.

The sampling area was no larger than $400 \mathrm{~m}^{2}$. All 1636 specimens were used in the electrophoretic analysis of 10 enzymatic systems with 16 loci:

Phosphogluconate dehydrogenase (PGD), phosphoglucomutase (PGM, 3 loci), $\beta$-galactosidase $(\beta-\mathrm{GAL})$, superoxide dismutase (SOD, 2 loci; anodal and cathodal), glyoxalase I (GLO), isocitrate dehydrogenase (IDH-1), leucine aminopeptidase (LAP, 2 loci), arylsulphatase (ARYL), esterases (EST, 3 loci; EST-1, EST2, EST-3), NADH diaphorase (DIA).

The samples were prepared from hepatopancreas and ovotestis for all enzymes except GLO, for which the digestive apparatus was used. Organs were homogenized with washed sea-sand and distilled $\mathrm{H}_{2} \mathrm{O}$ in the proportion of $1: 1$ weight/volume, centrifuged at $5000 \mathrm{rpm}$ for $15 \mathrm{~min}$ at $5^{\circ} \mathrm{C}$ and stored at $-80^{\circ} \mathrm{C}$.

Electrophoresis was in starch gel (Sigma) with the buffers and times shown in table 1 . The staining methods were according to Selander et al. (1971) and Harris et al. (1976). The alleles were named (a-e) from greater to lesser mobility.

To compare the grade of differentiation within and between zones, Wright's (1978) hierarchical $F$-statistics were used. Localities (demes) were considered grouped in eight regions according to geographical and climatic characteristics. The term $F_{\mathrm{DR}}$ estimates the variance for demes within the region; $F_{\mathrm{RT}}$, regions within the total area; $F_{\mathrm{DT}}$, demes within the total area.

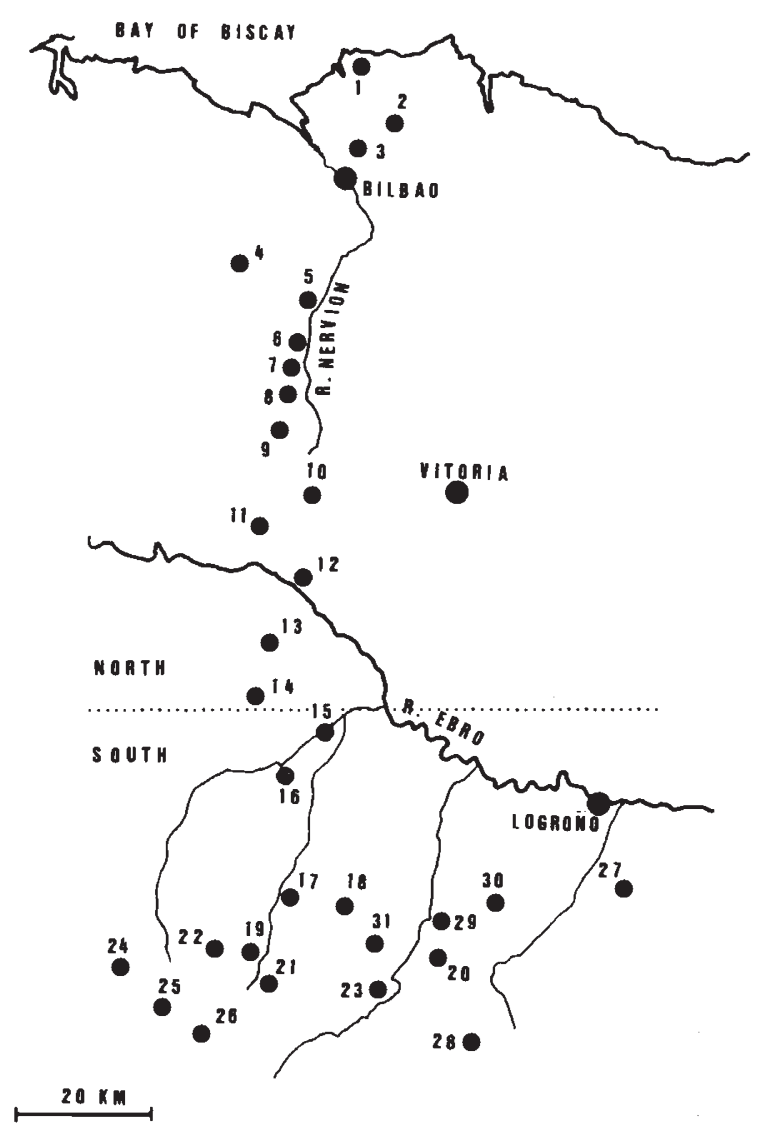

Figure 1 Area sampled in Spain

RESULTS

Sixteen loci were studied, of which PGM-1, $\beta$ GAL and ARYL were monomorphic in all populations. Two loci, IDH-1 and SOD-C, were monomorphic in almost all populations, and others occurred at low frequency, like $\mathrm{D}$ and $\mathrm{E}$ of PGM-2 and LAP-2, A of SOD and B and E of EST-2 (table 2). For EST-1 and LAP no presence of silent alleles was detected.

The variation between demes within each region $\left(F_{\mathrm{DR}}\right)$ is relatively high, and furthermore the degree of difference between the demes in each region is not uniform for the sixteen loci. Table 3 . The variation between regions $\left(F_{\mathrm{RT}}\right)$ is in all cases much less than within each region. Therefore, a greater component of diversity exists within the regions.

The most heterogeneous loci, by the measure $F_{\mathrm{ST}}$ are EST-3, PGM-3 and SOD. The $\chi^{2}$ heterogeneity analyses for each locus in each of the eight regions are significant. 
Table 1 Electrophoretic conditions and enzymes analysed

\begin{tabular}{|c|c|c|c|}
\hline Locus & Bridge buffer & Gel buffer & Volt and time \\
\hline PGD & $\begin{array}{l}0.13 \text { M Tris, } 0.07 \text { M Boric, } \\
0.003 \text { M EDTA, } p \mathrm{H}=8.7\end{array}$ & $\begin{array}{l}0.045 \text { M Tris, } 0.025 \mathrm{M} \text { Boric, } \\
0.001 \text { M EDTA, } p \mathrm{H}=8.9\end{array}$ & $8 \mathrm{~V} / \mathrm{cm} 5 \mathrm{~h}$ \\
\hline $\begin{array}{l}\text { PGM } \\
\text { DIA }\end{array}$ & $\begin{array}{l}0.23 \text { M Tris, } 0.05 \text { M Citric, } \\
p \mathrm{H}=8 \cdot 0\end{array}$ & $\begin{array}{l}1: 9 \text { Dilution of the bridge } \\
\text { buffer, } p \mathrm{H}=8.0\end{array}$ & $8 \mathrm{~V} / \mathrm{cm} 5 \mathrm{~h}$ \\
\hline $\begin{array}{l}\beta-G A L \\
\text { ARYL }\end{array}$ & $\begin{array}{l}0.22 \mathrm{M} \text { Tris, } 0.07 \text { M Citric, } \\
p \mathrm{H}=6.3\end{array}$ & $\begin{array}{l}1: 10 \text { Dilution of the bridge } \\
\text { buffer, } p \mathrm{H}=6 \cdot 3\end{array}$ & $8 \mathrm{~V} / \mathrm{cm} 5.5 \mathrm{~h}$ \\
\hline $\begin{array}{l}\text { GLO } \\
\text { SOD }\end{array}$ & $\begin{array}{l}0.21 \mathrm{M} \text { Tris, } 0.15 \mathrm{M} \text { Boric } \\
0.006 \text { EDTA, } 0.005 \mathrm{MgCl}_{2} \\
p \mathrm{H}=8.6\end{array}$ & $\begin{array}{l}1: 9 \text { Dilution of the bridge } \\
\text { buffer }+\mathrm{MgCl}_{2} \text { to } 0.005 \mathrm{M} \text {, } \\
p \mathrm{H}=8.6\end{array}$ & $8 \mathrm{~V} / \mathrm{cm} 5 \cdot 5 \mathrm{~h}$ \\
\hline $\begin{array}{l}\text { IDH } \\
\text { LAP }\end{array}$ & $\begin{array}{l}0.41 \text { M Sodium citrate, } 0.41 \\
\text { citric, } p \mathrm{H}=7.0\end{array}$ & $\begin{array}{l}0.005 \mathrm{M} \text { DL histidine, } 0.003 \\
\mathrm{MgCl}_{2}, p \mathrm{H}=7.0\end{array}$ & $10 \mathrm{~V} / \mathrm{cm} 5 \mathrm{~h}$ \\
\hline LAP & $\begin{array}{l}0.1 \mathrm{M} \text { Tris, } 0.1 \text { Maleic, } 0.01 \\
\text { EDTA, } 0.01 \mathrm{MgCl}_{2}, p \mathrm{H}=7.6\end{array}$ & $\begin{array}{l}1: 9 \text { Dilution of the bridge } \\
\text { buffer, } p \mathrm{H}=7.6\end{array}$ & $8 \mathrm{~V} / \mathrm{cm} 5 \mathrm{~h}$ \\
\hline EST & $\begin{array}{l}0.2 \mathrm{M} \text { Boric, } 0.03 \mathrm{M} \text { Lithium } \\
\text { HYDROXIDE, } p \mathrm{H}=8 \cdot 2\end{array}$ & $\begin{array}{l}0.02 \mathrm{M} \text { Boric, } 0.004 \mathrm{M} \text { Citric } \\
0.03 \mathrm{M} \text { Tris, } 0.003 \mathrm{M} \mathrm{LiOH} \\
p \mathrm{H}=8.2\end{array}$ & $12 \mathrm{~V} / \mathrm{cm} 6 \mathrm{~h}$ \\
\hline
\end{tabular}

All the polymorphic loci intervene in the analysis of principal components (APC). The first two axes explain 45 per cent of all variance. In fig. 2 it may be observed that the populations can be grouped in two areas, one located in the north of the sampled area, and taking in populations 1-14, and the other in the south, corresponding to populations $15-31$. Population 3 (Derio) is the only one which does not fit into its group. Within the southern area, a group of populations located in the east of the sampling area may be separated $(20,27,28,29)$.

To augment the explained variance, a dendrogram is constructed on the basis of the six principal axes (which explain 83.3 per cent of the total variance) (fig. 3). It may be observed that in the first ramification, the northern populations are separated from the southern ones, except populations $3,12,14$ and 15 . According to this analysis, the northern area is positively characterized by

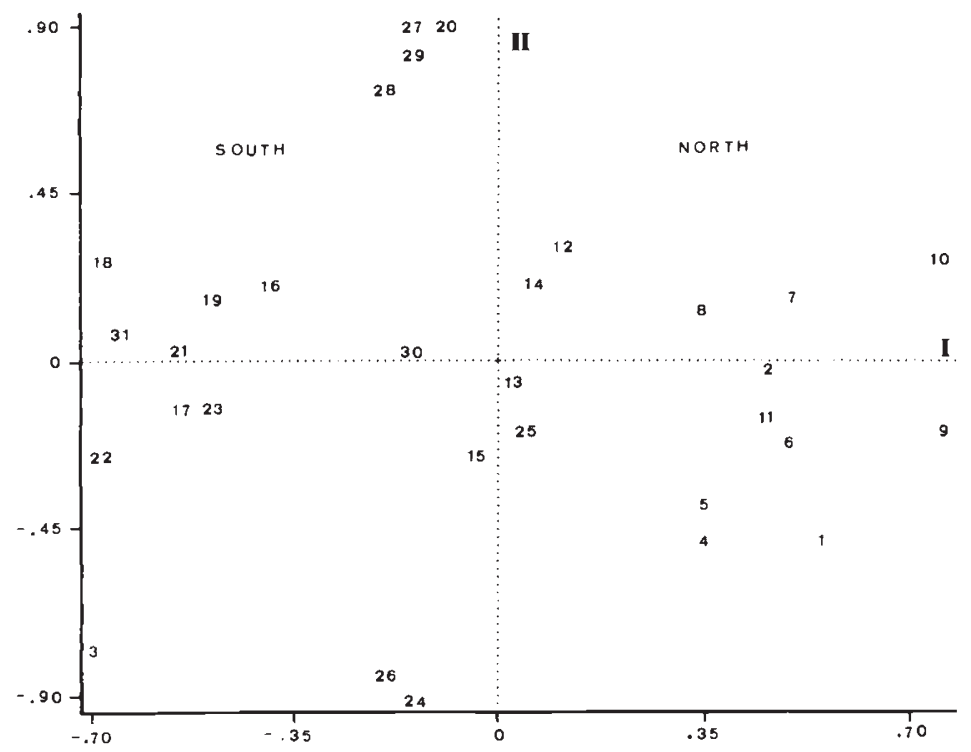

Figure 2 Distribution of populations on Factor I and II scores of analysis of principal component based on allele frequencies of 16 polymorphic enzymatic loci. Right of figure, northern populations; middle, intermediate populations; left, southern populations. (Numbers refer to localities in table 2). 
Table 2 Allelic frequencies of 16 enzymatic loci in 31 populations of Spain

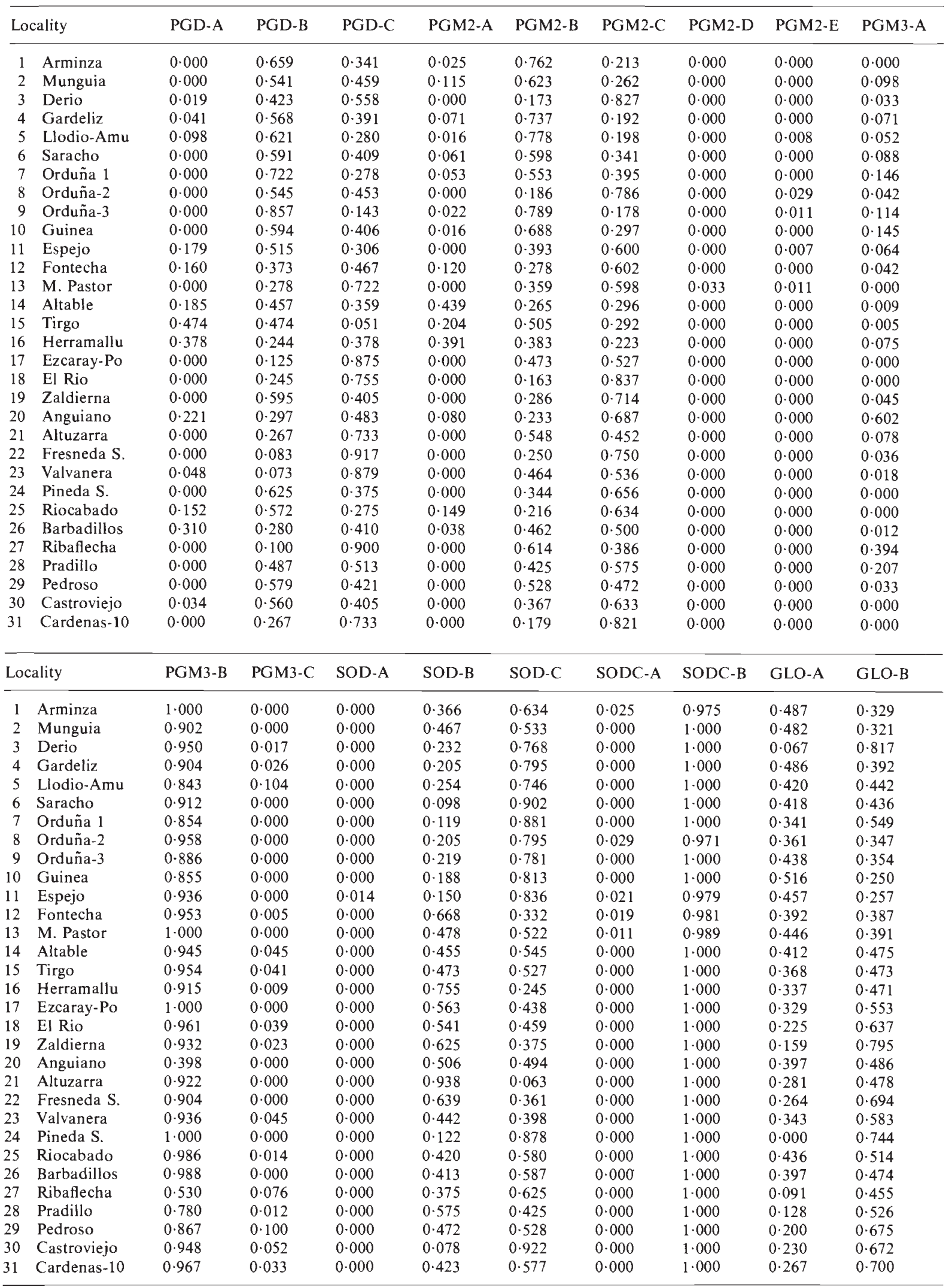


Table 2 continued

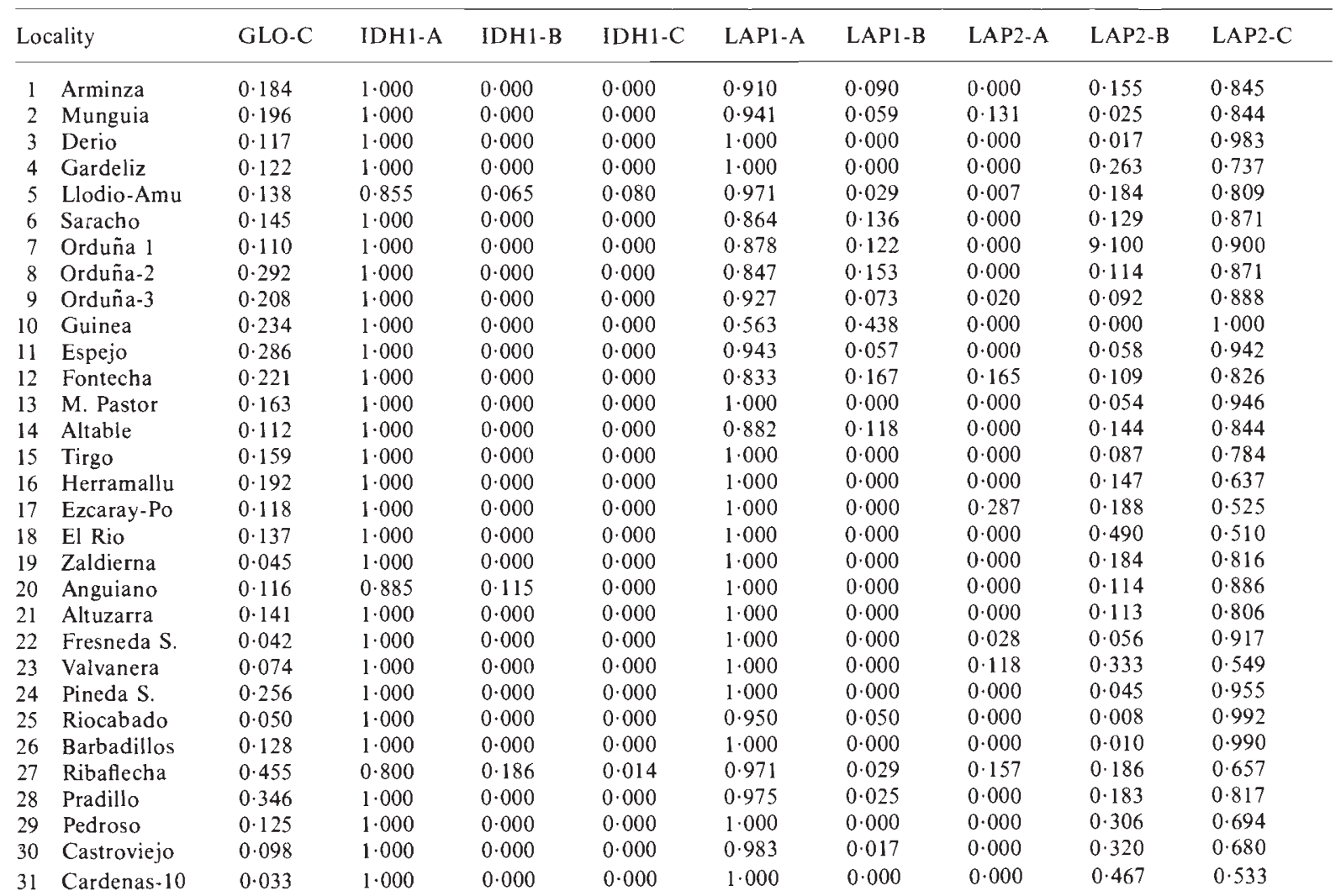

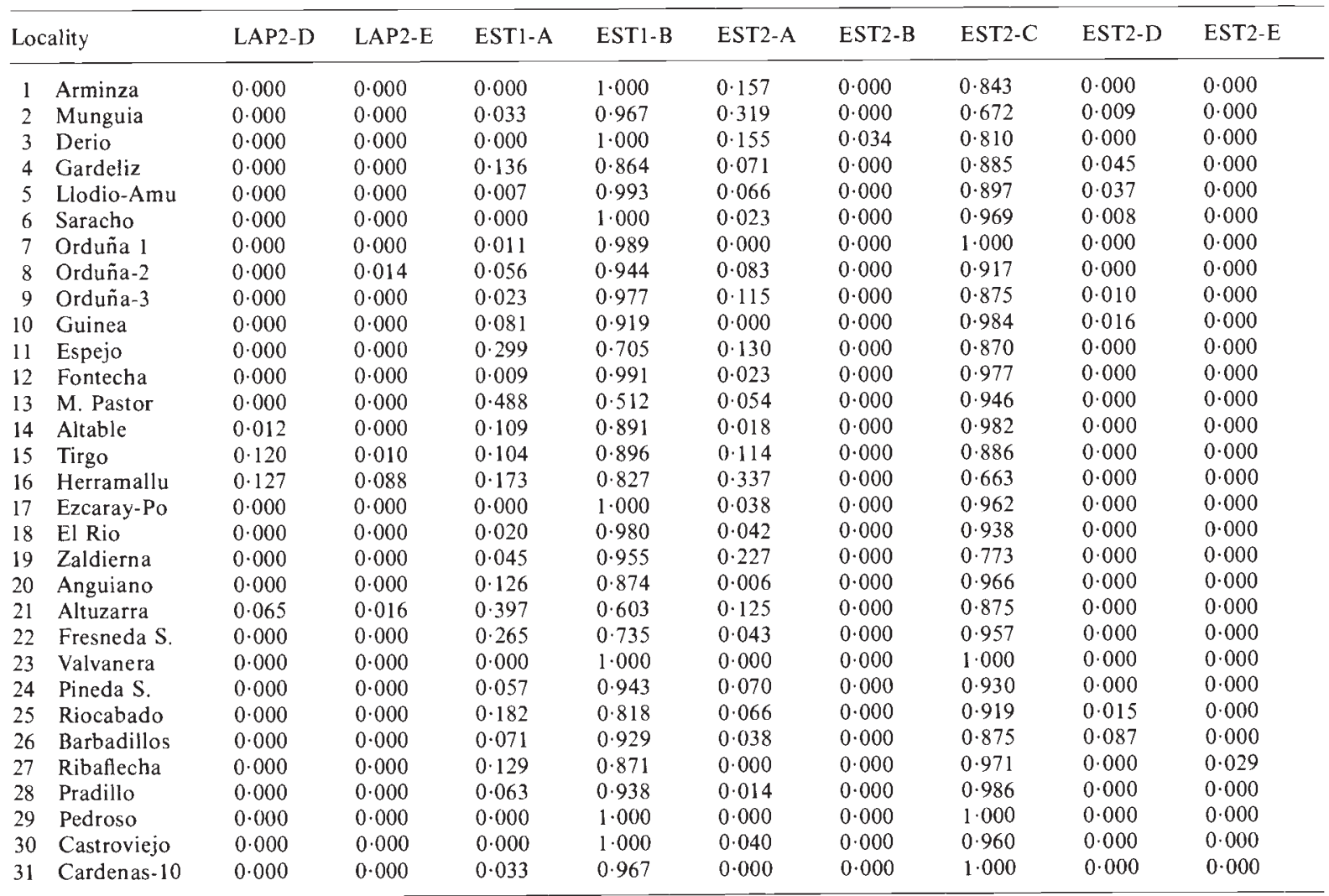


Table 2 continued

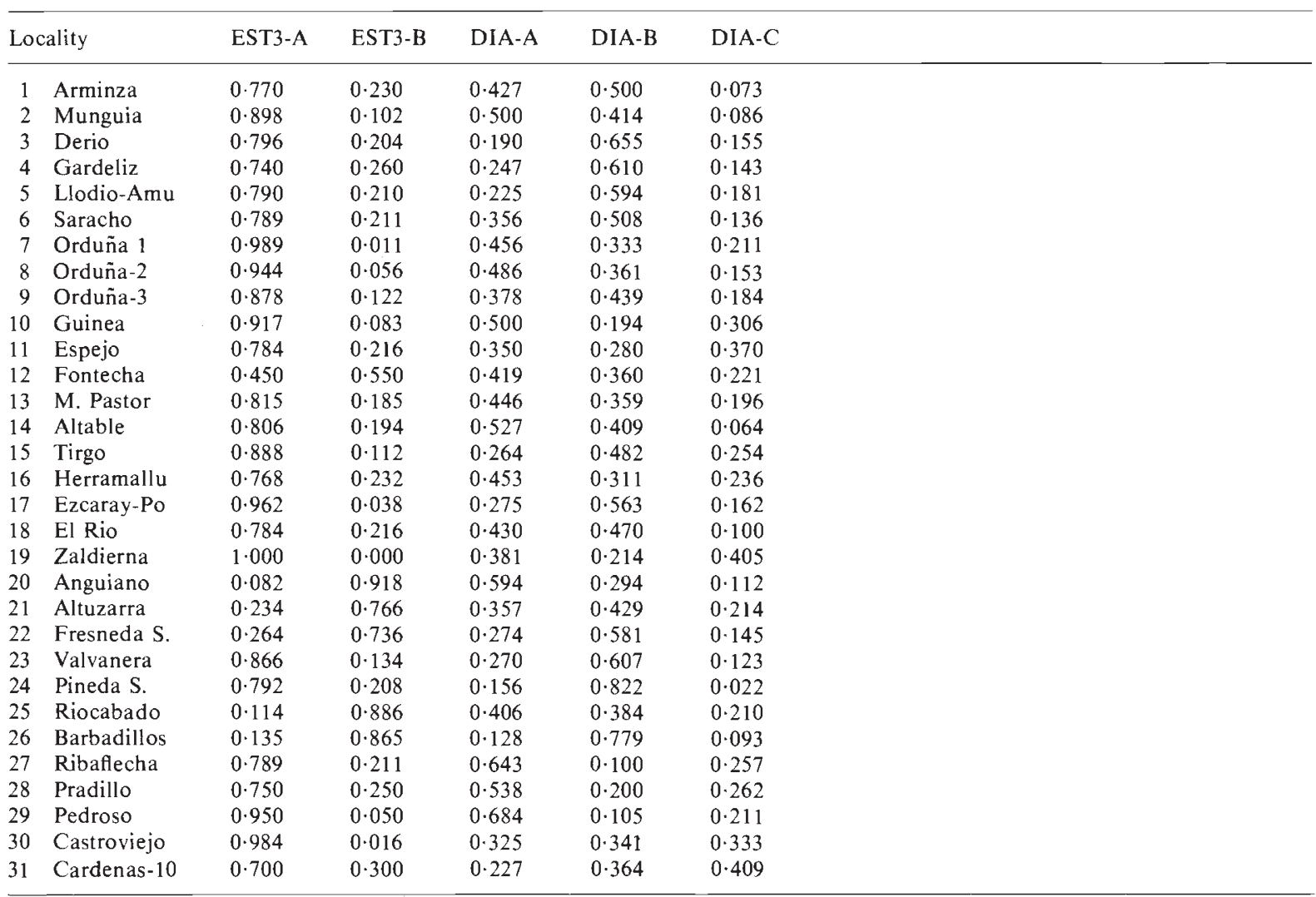

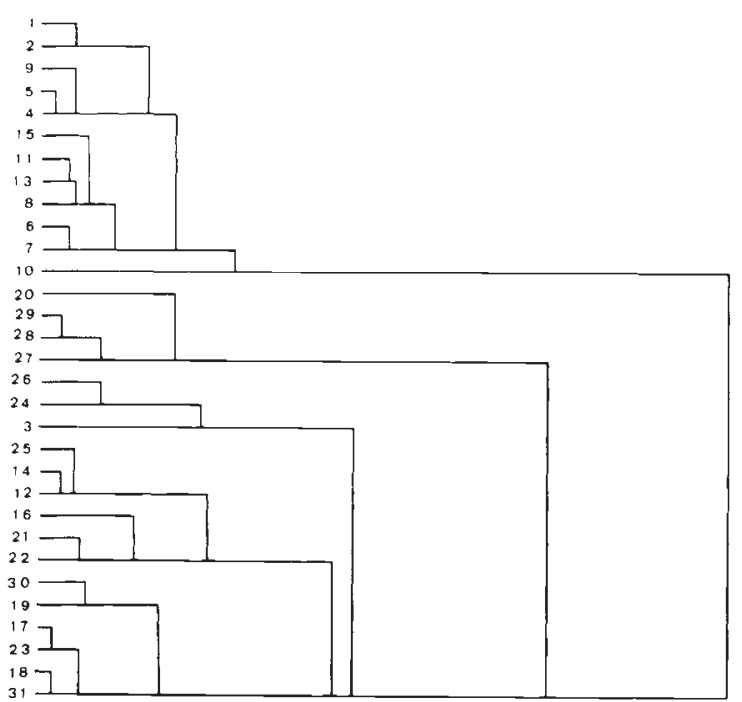

Figure 3 Hierarchy of populations for reciprocal neighbour method of six factorial axes with explained variance of 83.3 per cent.
GLO-A, PGM2-B, PGD-B, and the southern area by GLO-B, PGM3-B and DIA-B.

The main significant differences between north and south appear in table 4 , the results of which agree generally with the previous analyses.

Using Nei and Prevosti's genetic distance analysis, a dendrogram was constructed, (fig. 4), in which the north/south division is also seen. In this analysis, a series of populations may be observed which are classified at times in the north and at others in the south (12-16). Geographically, they are in the north/south separation area, which leads us to believe they correspond to a transitional area.

Heterozygosity is high in all populations. It ranges from 13.5 per cent in population 24 (Pineda) and 29.6 per cent in population 13 (M. Pastor), with the average being 21.5 per cent. In the northern area $(H=0.231)$ it is significantly higher than in the south $(0 \cdot 201)(t=2 \cdot 5, P=$ $0 \cdot 019$ ).

Although samples from the southern area are at greater mean altitude $(863 \mathrm{~m})$ than those in the 
Table 3 Hierarchical $F$-statistic for Cepaea nemoralis in Spain. Samples representing 31 localities (demes) $\left(F_{\mathrm{DR}}\right)$ in 8 regions $\left(F_{\mathrm{RT}}\right)$

\begin{tabular}{|c|c|c|c|c|}
\hline Locus & Freq. & $F_{\mathrm{DR}}$ & $F_{\mathrm{RT}}$ & $F_{\mathrm{DT}}$ \\
\hline \multicolumn{5}{|l|}{ PGD } \\
\hline A & $0 \cdot 061$ & $0 \cdot 141$ & 0.030 & $0 \cdot 167$ \\
\hline B & $0 \cdot 439$ & $0 \cdot 121$ & 0.034 & 0.151 \\
\hline $\mathrm{C}$ & $0 \cdot 500$ & $0 \cdot 147$ & $0 \cdot 012$ & 0.158 \\
\hline Mean & & $0 \cdot 135$ & $0 \cdot 024$ & 0.155 \\
\hline \multicolumn{5}{|l|}{ PGM-2 } \\
\hline A & 0.058 & 0.060 & $0 \cdot 151$ & $0 \cdot 203$ \\
\hline B & 0.440 & $0 \cdot 119$ & $0 \cdot 021$ & 0.138 \\
\hline C & $0 \cdot 449$ & $0 \cdot 118$ & 0.049 & $0 \cdot 161$ \\
\hline D & 0.001 & 0.019 & 0.002 & 0.021 \\
\hline$E$ & 0.002 & 0.002 & 0.002 & 0.004 \\
\hline Mean & & $0 \cdot 113$ & 0.047 & $0 \cdot 154$ \\
\hline \multicolumn{5}{|l|}{ PGM-3 } \\
\hline A & 0.078 & $0 \cdot 229$ & $0 \cdot 000$ & 0.206 \\
\hline B & 0.902 & $0 \cdot 182$ & 0.000 & $0 \cdot 171$ \\
\hline $\mathrm{C}$ & 0.020 & 0.017 & 0.000 & 0.028 \\
\hline Mean & & $0 \cdot 183$ & $0 \cdot 000$ & $0 \cdot 169$ \\
\hline \multicolumn{5}{|l|}{ SOD } \\
\hline A & $0 \cdot 001$ & 0.006 & $0 \cdot 001$ & 0.007 \\
\hline B & 0.402 & $0 \cdot 112$ & 0.063 & $0 \cdot 167$ \\
\hline $\mathrm{C}$ & 0.597 & $0 \cdot 110$ & 0.063 & $0 \cdot 166$ \\
\hline Mean & & $0 \cdot 111$ & 0.063 & $0 \cdot 167$ \\
\hline \multicolumn{5}{|l|}{ SOD-C } \\
\hline A & 0.997 & 0.004 & $0 \cdot 005$ & 0.009 \\
\hline \multicolumn{5}{|l|}{ GLO } \\
\hline A & 0.328 & 0.053 & $0 \cdot 018$ & 0.070 \\
\hline B & $0 \cdot 509$ & 0.056 & 0.024 & 0.079 \\
\hline C & $0 \cdot 163$ & 0.052 & 0.000 & 0.050 \\
\hline Mean & & 0.054 & $0 \cdot 016$ & 0.069 \\
\hline \multicolumn{5}{|l|}{ IDH-1 } \\
\hline A & 0.985 & 0.157 & 0.000 & $0 \cdot 140$ \\
\hline B & $0 \cdot 012$ & $0 \cdot 141$ & $0 \cdot 000$ & $0 \cdot 123$ \\
\hline $\mathrm{C}$ & 0.003 & 0.056 & 0.004 & 0.059 \\
\hline Mean & & $0 \cdot 140$ & $0 \cdot 000$ & $0 \cdot 125$ \\
\hline \multicolumn{5}{|l|}{ LAP-1 } \\
\hline A & 0.950 & $0 \cdot 107$ & 0.049 & $0 \cdot 150$ \\
\hline \multicolumn{5}{|l|}{ LAP-2 } \\
\hline A & 0.027 & $0 \cdot 174$ & $0 \cdot 000$ & $0 \cdot 146$ \\
\hline B & $0 \cdot 151$ & 0.079 & 0.030 & $0 \cdot 107$ \\
\hline $\mathrm{C}$ & 0.808 & 0.096 & 0.028 & $0 \cdot 121$ \\
\hline $\mathrm{D}$ & 0.010 & 0.044 & 0.049 & 0.090 \\
\hline $\mathrm{E}$ & 0.004 & 0.043 & 0.008 & 0.051 \\
\hline Mean & & 0.094 & $0 \cdot 024$ & $0 \cdot 116$ \\
\hline \multicolumn{5}{|l|}{ EST-1 } \\
\hline A & $0 \cdot 906$ & $0 \cdot 145$ & $0 \cdot 016$ & 0.159 \\
\hline \multicolumn{5}{|l|}{ EST-2 } \\
\hline A & 0.077 & 0.069 & $0 \cdot 028$ & 0.095 \\
\hline B & 0.001 & $0 \cdot 014$ & 0.002 & 0.017 \\
\hline $\mathrm{C}$ & 0.913 & 0.061 & $0 \cdot 024$ & 0.084 \\
\hline D & 0.007 & 0.032 & 0.004 & 0.036 \\
\hline$E$ & 0.002 & 0.021 & $0 \cdot 000$ & $0 \cdot 017$ \\
\hline Mean & & 0.062 & $0 \cdot 024$ & 0.085 \\
\hline \multicolumn{5}{|l|}{ EST-3 } \\
\hline A & 0.704 & $0 \cdot 357$ & 0.029 & $0 \cdot 376$ \\
\hline \multicolumn{5}{|l|}{ DIA } \\
\hline A & $0 \cdot 195$ & 0.059 & 0.010 & 0.068 \\
\hline B & 0.421 & 0.055 & $0 \cdot 061$ & $0 \cdot 113$ \\
\hline $\mathrm{C}$ & 0.384 & 0.033 & $0 \cdot 014$ & 0.046 \\
\hline Mean & & 0.051 & $0 \cdot 031$ & 0.080 \\
\hline Total & & $0 \cdot 123$ & 0.030 & 0.149 \\
\hline
\end{tabular}

Table 4 Significant differences in mean allelic frequencies between northern and southern zone of sampled area. ( $t$ of Student and probability)

\begin{tabular}{lllll}
\hline Allele & North & South & $t$ & $P$ \\
\hline PGD & & & & \\
B & 0.553 & 0.242 & 3.34 & 0.002 \\
C & 0.398 & 0.582 & 2.68 & 0.012 \\
PGM-2 & & & & \\
C & 0.413 & 0.566 & 2.13 & 0.042 \\
SOD & & & & \\
C & 0.706 & 0.508 & 2.92 & 0.007 \\
GLO & & & & \\
A & 0.409 & 0.261 & 3.56 & 0.001 \\
B & 0.410 & 0.589 & 3.93 & 0.000 \\
LAP-1 & & & & \\
A & 0.088 & 0.007 & 4.50 & 0.000 \\
B & 0.886 & 0.923 & 3.25 & 0.003 \\
LAP-2 & & & & \\
C & 0.879 & 0.750 & 2.7 & 0.011 \\
\hline
\end{tabular}

north $(416 \mathrm{~m})$, we found no correlation between altitude and heterozygosity. However, there do exist significant correlations between enzymatic loci and altitude (PGM2-B; PGM2-C; GLO-B) (fig. 5).

\section{DISCUSSION}

In this study, an electrophoretic analysis was made of ten organs of Cepaea nemoralis for all loci. The organs selected were those that gave best resolution. For example, the albumen gland for SOD, and the kidney for DIA, were rejected, since stains could be seen on the electrophoretic plate, and no bands were produced. In general, the hepatopancreas and the ovotestis were the organs that gave best band resolution. For GLO the digestive apparatus was used, as the rest of the organs probably expressed various loci whose alleles migrated very closely, making it very difficult to determine the different electromorphs. SOD-C is characteristic of the reproductive system. On the other hand, enzymes such as anodal $\beta-G A L$ were tested, but not included in the analysis because the electrophoretic variation pattern could not be determined.

Biochemical polymorphism of Cepaea nemoralis presents great variability between populations, which is similar to what happens with the visible polymorphism; but this is not so great as in the Pyrenees. No do we see here the fixing in nearby populations of alternative alleles (Caugant et al., 1982; Ochman et al., 1983). In this paper, new enzymes are introduced, such as $\beta$ GAL, ARYL, DIA and GLO. 

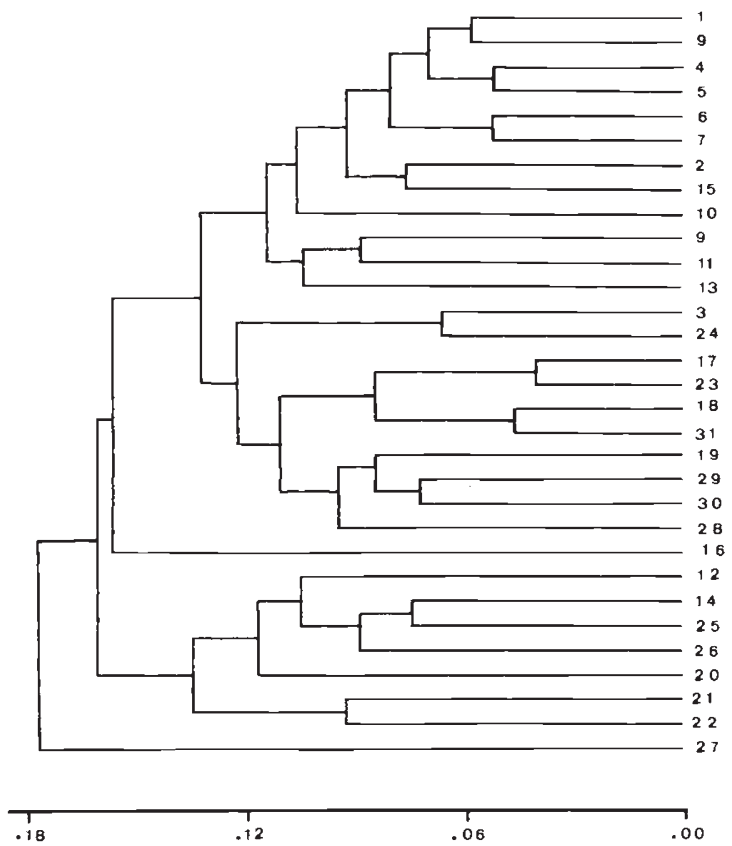

Figure 4 Dendrogram formed by UPGMA algorithm using Prevosti distance.

The heterogeneity of $F_{\mathrm{DR}}$ does not seem to support random genetic drift as the cause of the genetic differentation between localities. Both the $\mathrm{APC}$ and the dendrogram constructed on the basis of Nei and Prevosti's distance divide the area into two zones. This could be, on a smaller scale, the same phenomenon as observed by Ochman et al. (1987).

Heterozygosity is higher than average for Cepaea nemoralis $(0 \cdot 134)$ or for molluscs $(0 \cdot 148)$,

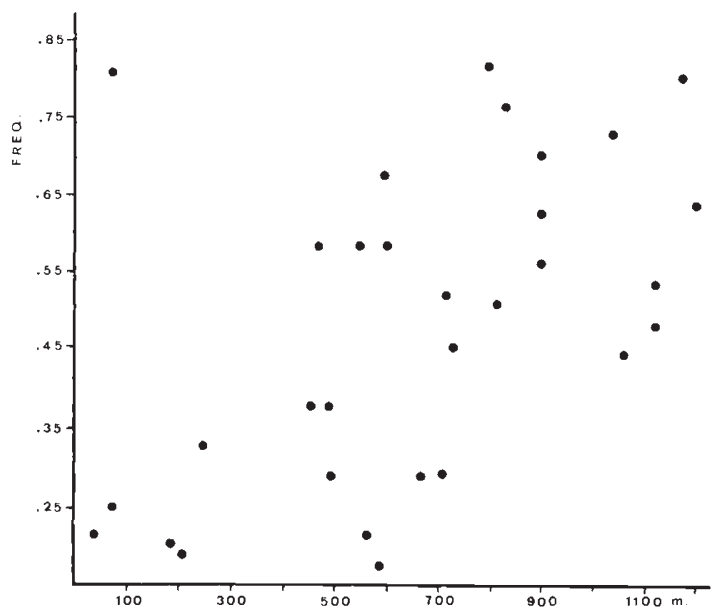

Figure 5 Representation of allele C of locus PGM2 for altitude in the North of Spain. but does not reach the values of 0.644 found for Modiolus auriculatus or 0.635 for Cerithium caeroleum (Selander and Ochman, 1983; Nevo, 1984).

The northern zone of our sampling area is characterised by an Atlantic climate-very rainy, with mild temperatures-while the southern zone has a continental climate-very dry, with extreme temperatures-and the average altitude in the south is greater than in the north.

Heterozygosity is significantly higher in the north than the south. This could be in accordance with the situation described by Nevo (1984) for molluscs and other taxa in which heterozygosity diminishes in those species which live in extreme areas (arid or extra-mesic). Furthermore, this process in Cepaea nemoralis could be of greater importance, since in the sampling area we are approaching the southern limit of its distribution.

Valdez-Forsans (1983) also found a reduction in heterozygosity in the highest areas of the Ariege valley in the French Pyrenees. In the southern Pyrenees Caugant et al. (1982) found no correlation between heterozygosity and altitude, but the higher populations were significantly less heterozygous than those from localities at medium or low elevations. This decrease in heterozygosity in unfavourable conditions could be a general process in Cepaea nemoralis. This could agree with the niche width variation hypothesis.

There are a series of coincidences between the visible (Mazon et al., 1987) and biochemical polymorphism studied in the same area: (a). The subdivision of the populations into two zones according to biochemical polymorphism coincides with the subdivision observed for the visible. Furthermore, the point of division is the same. Population 3 (Derio) was classified in the southern zone for visible polymorphism and for biochemical polymorphism when geographically it corresponds to the north. The intermediate area between the two zones (transitional zone) is also the same for both polymorphisms. (b) The southern zone is more heterogeneous than the north for both visible and biochemical polymorphisms. This may be seen clearly in the dispersion of the populations in the APC and in the greater distances observed in the dendrograms for the southern zone. A relationship between visible and biochemical polymorphism exists in some cases (Johnson, 1976) and not in others (Jones et al., 1980; Caugant et al., 1982; Ochman et al., 1983).

The concordance of climatic zones with the zones of biochemical polymorphism leads us to ask the question, are the enzymatic loci subject to 
climatic selection? In our case, we feel that some loci may indeed be subject to selection, since the loci which contribute most to the formation of the zones are some of those which are correlated with altitude (PGM, GLO). On the other hand, others, which have great variance (EST3, PGM3, SOD) are not so important in the formation of zones, although it is difficult to understand the selection mechanism upon these loci.

At microgeographical level, adaptive effects have been observed for enzymatic loci in snails, which are probably due to microclimate diversifying selection (Nevo, 1982). However, in Ochman's large scale study (1987) he finds very few correlations between allele frequency changes and environmental components, although selection cannot be excluded. On the other hand, on a small scale there is evidence for the action of selection. We are extending this study to other areas, and extending the number of enzymatic loci to include those studied by other authors.

To sum up, the coincidence of the subdivision created by visible and biochemical polymorphism, the different heterozygosity in each zone, the correlation of some loci with altitude and heterogeneity of $F_{\mathrm{DR}}$ are good arguments in favour of the differentiation of these two zones into two possible "geographical races", possibly due to climatic selection.

\section{REFERENCES}

BRUSSARD, P. F. AND McCRACKEN, G. F. 1974. Allozymic variation in a North American colony of Cepaea nemoralis. Heredity, 33, 98-101.

CAIN, A. J. AND CURREY, J. D. 1963. Area effects in Cepaea on the Larkhill artillery ranges, Salisbury Plain. J. Linn. Soc. (Zool.), 45, 1-15.

CAUGANT, D., SELANDER, R. K. AND JONES, J. S. 1982. Geographic structuring of molecular and morphological polymorphism in Pyrenean populations of the snail Cepaea nemoralis. Genetica, 57, 177-191.

HARRIS, H. AND HOPKINSON, D. A. 1976. Handbook of Enzyme Electrophoresis in Human Genetics. North-Holland, Amsterdam.

JOHNSON, M. S. 1976. Allozymes and area effects in Cepaea nemoralis on the Western Berkshire Downs. Heredity, 36, 105-121.
JOHNSON, M. S. 1979. Inheritance and geographic variation of allozymes in Cepaea nemoralis. Heredity, 43, 137-141.

JONES, J. S., LEITH, B. H. AND RAWLINGS, P. 1977. Polymorphism in Cepaea: A problem with too many solutions? Ann. Rev. Ecol. Syst., 8, 109-143.

JONES, J. S., SELANDER, R. K. AND SCHNELL, G. D. 1980. Patterns of morphological and molecular polymorphism in the land snail Cepaea nemoralis. Biol. J. Linn. Soc., 14, 359-387.

LEVAN, G AND FREDGA, K. 1972. Isozyme polymorphism in three species of land snails. Hereditas, 71, 245-252.

MANWELL, C. AND BAKER, C. M. A. 1968. Genetic variation of isocitrate, malate and 6-phosphogluconate dehydrogenases in snails of the genus Cepaea. Introgressive hybridization, polymorphism and pollution? Comp. Biochem. Physiol., 26, 195-209.

MAZON, L. I., M. PANCORBO, M. A., VICARIO, A., AGUIRRE, A. I., ESTOMBA, A. AND LOSTAO, C. M. 1987, Distribution of Cepaea nemoralis according to climatic regions in Spain. Heredity, 58, 145-154.

NEVO, E. BAR-EL, C. BEILES, A. AND YOM-TOU, Y. 1982. Adaptive microgeographic differentiation of allozyme polymorphism in land snails. Genetica, 59, 61-67.

NEVO, E., BEILES, A. AND BEN-SHLOMO, R. 1984. The evolutionary significance of genetic diversity: Ecological, demographic and life history correlates. In Mani, G. S. (ed.) Evolutionary Dynamics of Genetic Diversity, SpringerVerlag. Berlin, pp. 13-213.

OCHMAN, H., JONES, J. S. AND SELANDER, R. K. 1983. Molecular area effects in Cepaea. Proc. Natl. Acad. Sci. USA, 80, 4189-4193.

OCHMAN, H., JONES, J. S. AND SELANDER, R. K. 1987. Large scale patterns of genetic differentiation at enzyme loci in the land snails Cepaea nemoralis and Cepaea hortensis. Heredity, 58, 127-138.

OXFORD, G. S. 1973. The genetics of Cepaea esterases. I. Cepaea nemoralis. Heredity, 30, 127-139.

SELANDER, R. K., SMITH, M. H., YANG, G. Y., JOHNSON, W. E. AND GENTRY, J. B. 1971. Biochemical polymorphism and systematics in the genus Peromyscus I. Variation in the old-field mouse (Peromyscus polionotus). Studies in Genetics, 6, 49-90.

SELANDER, R. K. AND KAUFMANN, D. W. 1975. Genetic structure of populations of the brown snail (Helix aspersa). I. Microgeographical variation. Evolution, 29: 385-401.

SELANDER, R. K. AND OCHMAN, H. 1983. The genetic structure of populations as illustrated by molluscs. In Isozymes: Current Topics in Biological and Medical Research, Vol. 10, Alan, New York, pp. 93-123.

VALDEZ-FORSANS, M. 1983. Variabilité enzymatique dans les populations du Mollusque Cepaea nemoralis (L.) de la vallée de Ariege, Pyrénées francaises. C.R. Acad. Sc. Paris, 296, 1045-1047.

WHITE, M. J. D. 1978. Modes of Speciation. W. H. Freeman, San Francisco.

WRIGHT, S. 1978. Evolution and Genetics of Populations, vol IV, Variability Within and Among Natural Populations. Univ. of Chicago Press. Chicago. 